\title{
Evaluating Information-processing-based Learning Cooperative Model on Speaking Skill Course
}

\author{
Agus Darmuki \\ Indonesia Education Department of SebelasMaret Surakarta State University, Indonesia; \\ IKIP PGRI Bojonegoro, East Java, Indonesia \\ Andayani \\ Sebelas Maret University, Central Java, Indonesia \\ Joko Nurkamto \\ Sebelas Maret University, Central Java, Indonesia \\ Kundharu Saddhono \\ Sebelas Maret University, Central Java, Indonesia
}

\begin{abstract}
The speaking ability of university students is still low due to the lack of information, interaction, and critical ideas in oral communication. Cooperative learning was implemented as the approach to overcome it. The research aimed at: (1) evaluating the effectiveness of cooperative approach in terms of the development of student's speaking ability, the effectiveness of speaking learning activity, and the learning instruction of guidance book; 2) figuring out the significant difference result pre and post cooperative model. The researcher employed mixed method approach (a combination of descriptive-evaluative and experimental designs) to evaluate cooperative model applied for Indonesian Language and Literature Department at IKIP PGRI Bojonegoro, Ronggolawe University in Tuban, and Darul Ulum Islamic University in Lamongan. The research sample was $50 \%$ of the total population by purposive sampling technique. The research instruments (questionnaire, interview, and speaking test) were previously tested their validity and reliability. Data analysis (questionnaire and interview) have some phases: data reduction, data presentation, and conclusion drawing. The normality and homogeneity of data resulted from speaking test were tested by t-test. To evaluate learning model or obtain input from related lecturers, students, and the researcher himself, the activity of Focus Group Discussion (FGD) was utilized. The students taught by cooperative model have the speaking score of 18.9875,

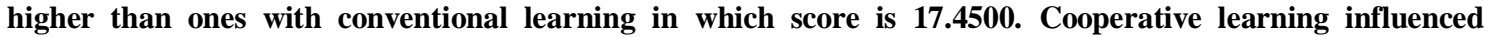
significantly student's speaking ability as $F_{\text {calculation }}>F_{\text {table }}$ in which $F_{\text {calculation }}$ test obtained 11.380 while $F_{\text {table }}$ was 3.91 at the significance level $=0.05$.
\end{abstract}

Index Terms - model, evaluation, cooperative learning, information process, speaking ability

\section{INTRODUCTION}

Education field abounded with communication activity asks students to arouse their abilities to communicate well, both spoken and written (Darmuki, 2013). At the university level, students are demanded to communicate critically, speaking in particular (Maarof, 2012). Department of Indonesian Education offers a curriculum of speaking competence, exactly in Speaking course which aims at actualizing speaking ability in the daily life.

Along with the betterment of democracy condition, the speaking skill of students as the agent of change is really necessary in society. Speaking gives crucial contribution to students in order to have better communication skill (Rido et all, 2013). Learning process needs communication as the signal of effective and efficient interaction inside (Bahrani \& Rahmatollah Soltani, 2008). Besides, the opportunity for students to speak directly is really needed to improve their speaking skill (Liao, 2009); (Alibakhsi \& Padiz, 2011). A lecturer has to implement the management of interaction and elicitation upon the speaking technique to improve students' participation and create learning opportunity (Darmuki, 2013:75). Class interaction is really helpful for language learning (Rahman, 2014:1). The actualization of university students as the next generation is recognized from speaking ability. Students of Indonesian Language and Literature Department as the candidate of Indonesian teachers should be taught curriculum competence.

During the learning process at Education Institution of Teacher, many students have low speaking ability. They do not respond the learning process in the class. They as teacher candidates are expected to speak effectively. Effective communication only happens when the message can be received correctly by the receiver (Daryanto, 2010:59). To communicate effectively, a teacher candidate has to be able to process information well because information processing 
refers to learning process (Wardhani, 1997:17). Teacher's success is characterized by attitudes of serious attention, never give up, understandable explanation, and good class management (Marland, 1990:13-14).

Teachers have essential roles in creating effective communication in the class. They must have influential factors such as personality, material acquisition, classroom management, speaking ability, classroom circumstance conditioning, having individuality principle, and open-minded (Suryobroto, 1997:163-164). Thornbury (2001:112) in How to Teach Speaking stated that a teacher should make a well lesson plan in teaching speaking by involving some steps as follows: (1) integrate speaking activity in the curriculum, (2) organize speaking activity in the syllabus, (3) have class discussion, (4) assess speaking activity, (5) give criteria of speaking assessment. In fact, the students have low ability in communication because they have low motivation on the speaking material. Besides, they do not have relevant information in their memories. In this case, having knowledge is not sufficient for teachers but they should also have the ability to deliver it to students.

Nurgiyantoro (2011:86) said that a productive language competence means the ability to produce language to be delivered to others. Productive language activity refers to speaker's activity to convey ideas, thoughts, feeling, and information messages. A speaker must have materials for speaking activity. Speaking merely means the ability to convey messages orally. Brown and Yule (2012:2) proposed speaking as the ability to pronounce language sounds to express or convey thought, ideas, and feeling orally. In line with the above opinion, Burhan Nurgiantoro (2011:276) argued that speaking is the second language activity done by human after listening. Speaking constitutes the ability to pronounce words (articulation sound) expressed to convey thoughts or ideas. St. Y. Slamet (2008:31) defined speaking as a communication tool commonly used in society. Go along with the previous definitions, speaking is a communication activity which invokes relationship between the speaker as the sender and the receiver as the listener (Darmuki:28). Thus, it can be concluded that speaking skill is producing articulation sound by processing the existing information in delivering ideas/thoughts, feeling, and desire to others.

Communication refers to deliver, receive, and transfer messages, ideas, opinions, and feeling (Sinayah et al, 2015:233-245). Communication is an important and complex thing as has been proposed by Leo F. Parvis (2001, Vol. 63 ) in his article entittled "The Importance of Communication and Public-Speaking Skill" as follows:

Communication, a complex process, is not an easy skill to perfect. Nevertheless, it is the most significant skill in human life. We hear this from the voices quoted in Karen Casey and Martha Vanceburg's Promise of a New Day: A Book of Daily Meditations: "What most of us want is to be heard, to communicate," says one. A second believes that "To live in dialogue with another is to live twice. Joys are doubled by exchange and burdens are cut in half". Life becomes so easy with communication. This necessity of life, however, must be done right.

Speaking becomes an essential skill that must be acquired by university students. Through good speaking skill, they can convey desire, information, thoughts, and ideas as well as persuade, convince, ask, and entertain others. Speaking activity reflects someone's ability to think.

Cooperative learning refers to a broader concept which comprises all group work particularly done under lecturer's direction (Andayani, 2014:195). In cooperative class, students are expected to help, discuss, and argue each other in order to sharpen their existing knowledge and close their gap in understanding (Slavin, 2009:4-8). Sugiyanto (2010:37) defined cooperative learning as the learning model which focuses on small groups of students to cooperate in maximizing the learning condition to achieve learning objectives. This model assists students to find new information, learn important skills, and process information obtained from previous learning (Arends, 2008:4). Riyanto (2010:267) stated cooperative learning as a learning model designed to teach academic skill as well as social and interpersonal skills.

Arends (2008:5) stated three purposes of cooperative learning i.e. academic achievement, tolerance, heterogeneity acceptance, and social skill development. Whereas Riyanto (2010:267) formulated the objective of cooperative learning based on its feature, they are individual, competitive, and cooperative. Principles underlines cooperative learning are positive independence, face to face instruction, individual accountability, use of collaborative/social skill, and group processing. Thus, cooperative learning contains some elements: (1) develop interaction which loves, educate, and foster each other as a life training in society; (2) positive interdependence; (3) individual responsibility; (4) face to face in learning process; (5) inter-group-member interaction; (6) evaluation on learning process through group.

The assumption of information processing are: (1) information processing happens at the stage of separating stimulus acceptance and response provision; (2) the analogy of information processing is computer processing (receiving information, keeping it in memory, getting it out whenever it is needed); (3) information processing involves all cognitive activities such as seeing, feeling, repeating, thinking, solving problems, remembering, forgetting, and telling.

\section{Information-Processing-Based Learning Cooperative Model in Speaking}

Cooperative Learning can be noticed from task structure, objective, and cooperative reward. Some features inside Cooperative Learning are as follows: (1) students work in a team to achieve learning objectives; (2) a team consists of students' achievement of low, medium, and high; (3) a team comprises a blend of race, culture, and gender; (4) reward system focuses on group and individual.

Cooperative learning on speaking follows some steps: (1) give information, objective, and learning scenario (the given information must be so familiar that it can be related to the discussed information); (2) organize students in 
heterogenic; (3) guide students to cooperate each other (speaking activity is optimized for each individual); (4) evaluate performance by having group work presentation (the best presenter is asked to perform); (5) give reward.

Teaching and learning process can be carried out through network. Teacher can ease the process by helping students to relate new information with the existing knowledge in their memories. Meaningful information which then is explained, developed, and organized will be easy to merge in the network of Long Term Memory (LTM). Cognitive theories give many emphasizes on students 'information processing as the main cause of learning.

\section{Evaluation on Cooperative-Approach-Based Speaking Learning Model}

The general aim of speaking assessment is to figure out student's speaking ability. This aim is broken down into specific aim exactly to know the level of ability to express opinion, ideas/thought during discussion, question-answer, tell a story, give a speech and so forth. The means for measuring the speaking skill evaluation were test and non-test. There were two factors of speaking activity being assessed i.e. (1) language which comprises pronunciation, consonant, stress, articulation, rhyme, diction, expression, word variation, form, sentence structure, and sentence variation, (2) courage and passion which involves fluency, voice loudness, eye catching, movement and mimic, openness, reasoning and topic acquisition (Arsjad, 2008:87).

Evaluating someone's speaking skill, basically, must consider five factors: 1) are certain sounds (consonant) pronounced well, 2) are intonation patterns, sound decrease and increase, as well as syllable stress satisfying, 3) do the consistency and accuracy of pronunciation reflect that the speaker understands his/her language without internal reference, 4) are the pronounced words in the correct form and sequence, 5) how can someone's speaking reflects customary, fluency, or native-speaker sounds? (Tarigan, 2008:28).

Speaking assessment contains two aspects namely psychomotor and cognitive abilities. The former can be noticed from fluency and natural gestures while the latter comprises: (1) information accuracy; (2) inter-information relation; (3) structure and vocabulary accuracy; (4) fluency; (5) passage sequence customary; (6) pronunciation style (Nurgiantoro, 2001:278-292). The scoring rubric for oral language uses the model of O'mally and Pierce (1996:67) which is in line with Bailey's concept (2005:42) in which language features are comprehension, pronunciation, vocabulary, grammar, and fluency. Based on the above opinions, it can be concluded that this research implements authentic assessment by observing and assessing student's performance on speaking in front of the class.

\section{Methodology}

The research setting for model evaluation trial was at three universities i.e. IKIP PGRI Bojonegoro, Ronggolawe University-Tuban, and Darul Ulum Islamic University-Lamongan. The researcher employed the research design proposed by Fraenkel and Wallen (1990:237) namely two trial groups. One functioned as control group while the other functioned as experimental group. Both groups were given pre-test. Control group was treated by the usual learning model used at the campus so far. Experimental group was taught by the developed learning model of speaking skill. The different achievement of both groups was then compared. Interview and questionnaire were also implemented to know the response and suggestion from lecturers and students about the applied learning model.

The research populations were students of Indonesian Language and Literature Education Department at IKIP PGRI Bojonegoro, Tuban, and Lamongan, while its samples were those of the first semester. Stratified random sampling was used as the sampling technique which based on the class quality at each campus (high, medium, and low). The research instruments were as follows:

1. Questionnaire

Some relevant literatures were used to develop the researcher's questionnaire by reviewing the learning model with cooperative approach. To obtain validity and delete the questionnaire ambiguity, the promoter and the lecturer of speaking course checked it.

2. Interview

The interview was intended for collecting information about lecturer perception and suggestion on the effectiveness of approach-based cooperative learning model. Interview guidance involves opened questions about evaluation, effectiveness, lecturer's learning objectives, and improvement on the learning model.

3. Speaking Skill Test

The speaking test aimed at to figure out the effectiveness or differences before and after using cooperative approach.

4. Focus Group Discussion (FGD)

FGD activity involved one lecturer of Surakarta State University as the expert in learning model development, some lecturers of speaking course, some students as the samples, and the researcher himself. This activity purposed to determine the strengths and weaknesses of cooperative-approach-based learning model.

The data analysis techniques utilized triangulation of mix-method design (a mixture of quantitative and qualitative research method) with embedded type by analyzing simultaneously to understand the research problem. In this case, quantitative data provide ways to make temporary generalization while qualitative ones reserved information on context and place.

Quantitative test was done by t-test in which the researcher used statistical program of SPSS to obtain fast and accurate data calculation. Qualitative descriptive analysis was carried out on the data of validation sheet and observation sheet of implementation phase. Besides, qualitative analysis aimed at describing students' speaking skills during the 
learning process. The following data triangulation was conducted by analyzing both qualitative and quantitative data separately and then compared the results. Finally, the researcher made interpretation whether the data supported or opposed each other.

This research is a part of dissertation to be exact on the effectiveness test which aimed at testing the effectiveness of cooperative approach applied at three universities of IKIP PGRI Bojonegoro, Ronggolawe University in Tuban, and Darul Ulum Islamic University in Lamongan, East Java, Indonesia. The last phase called experimental phase/effectiveness test on the learning model with R\&D research design was proposed for the scheme of Doctoral Dissertation Research. The figure below is the detail of $R \& D$ research stages which also became a research of doctoral dissertation:

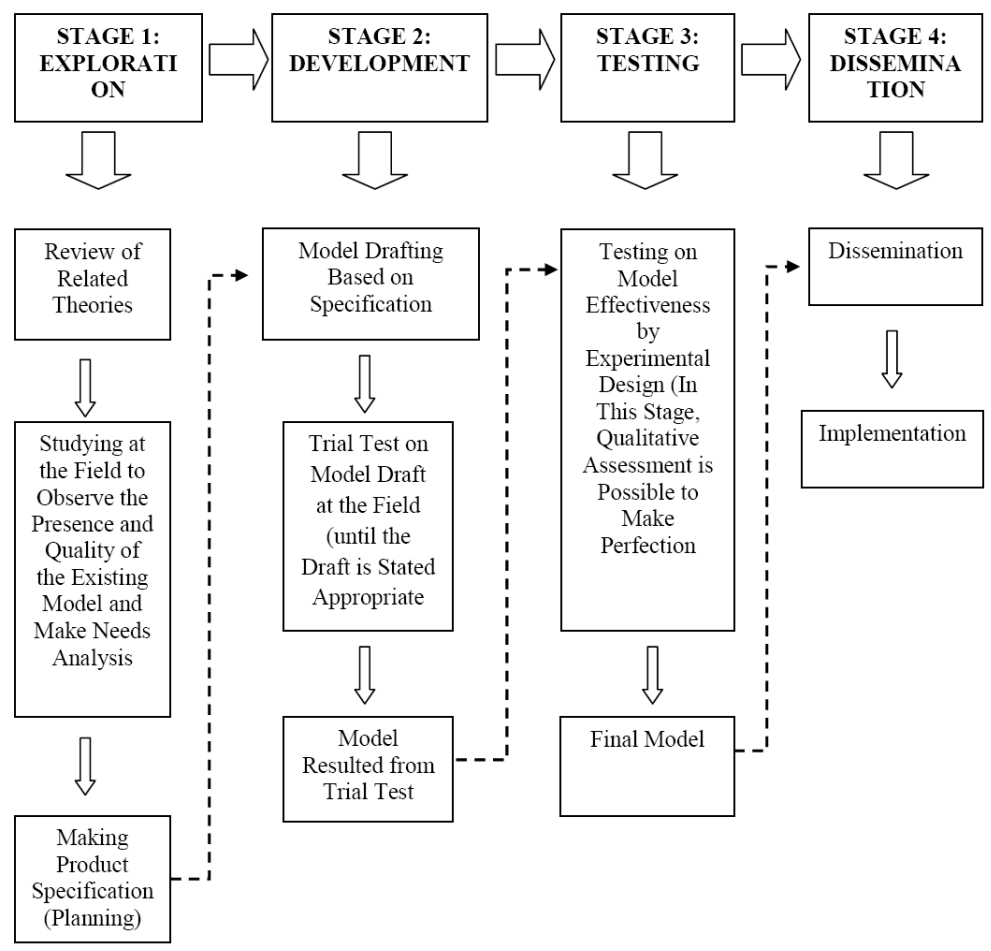

Figure 1. The Development Model of Research Adopted from Sukmadinata (2007)

\section{RESULTS AND DISCUSSION}

To show the effectiveness level of learning, the speaking ability before and after treatment must have comparison test. Before having speaking treatment, the speaking ability of students from both cooperative and conventional classes was relatively the same. However, after the students had got treatment, their speaking ability showed improvement by cooperative learning than by conventional one.

Based on the statistical test, $\mathrm{F}_{\text {calculation }}$ between before and after the treatment obtained 57,062, while $\mathrm{F}_{\text {table }}$ was 3.91 at

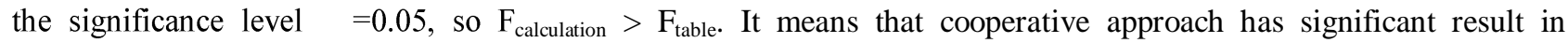
improving students' speaking ability at the university level $(13.7531<16.3210)$.

After the students had obtained treatment of cooperative and conventional learning, their achievement showed different speaking abilities. The students with cooperative learning have the average score of speaking 16.3210, higher than ones with conventional learning in which score was 14.7654. Statistically, both scores are different because $\mathrm{F}_{\text {calculation }}>\mathrm{F}_{\text {table }}$ which derives from the analysis result of Anava test indicating $\mathrm{F}_{\text {calculation }}$ of 22.141, $\mathrm{F}_{\text {table }}$ of 3.91 at the significance level $=0.05$. This difference indicated that cooperative learning gave significant influence to students' speaking ability.

The Analysis Result of Anava Test on Students Data

TABLE 1.

SUMMARY ON ANAVA TEST RESULT AT INDONESIAN LANGUAGE AND LITERATURE EDUCATION

\begin{tabular}{|l|l|l|l|l|l|l|l|}
\hline No & Group & Sum Squares & df & Mean Squares & $\mathbf{F}_{\text {calculation }}$ & $\mathbf{F}_{\text {table }}$ & P \\
\hline 1 & I & 21.025 & 1 & 21.025 & 2.476 & 3.91 & $<0.05$ \\
\hline 2 & II & 94.556 & 1 & 94.556 & 11.380 & 3.91 & $>0.05$ \\
\hline 3 & III & 257.556 & 1 & 257.556 & 30.810 & 3.91 & $>0.05$ \\
\hline 4 & IV & 119.025 & 1 & 119.025 & 14.100 & 3.91 & $>0.05$ \\
\hline
\end{tabular}

Notes: 
I: The comparison of students' speaking scores of Indonesian Language and Literature Department between experimental and control groups pre treatment

II: The comparison of students' speaking scores of Indonesian Language and Literature Department between experimental and control groups post treatment

III: The comparison of students' speaking scores of Indonesian Language and Literature Department on both experimental groups pre and post treatment

IV: The comparison of students' speaking scores of Indonesian Language and Literature Department on both control groups pre and post treatment

Based on the analysis result of statistical data, the average score of speaking ability before having treatment was 16.4500 at experimental class and 15.7250 by conventional learning. $F_{\text {calculation }}>F_{\text {table }}$ as $F_{\text {calculation }}$ was 2.476 while $F_{\text {table }}$ was 3.91 at the significance level $=0.05$. It means that before having treatment, both cooperative and conventional classes are quite the same in terms of student' speaking ability. The average scores of speaking ability after having treatment are 18.9875 by cooperative learning and 17.4500 by convention learning.

The effectiveness level of learning pre and post treatment can be noticed from comparison test on speaking ability scores before and after treatment of cooperative and conventional learning. The average scores of speaking ability pre treatment for both classes are relatively the same. However, after having treatment, there was improvement in speaking ability.

Based on the statistical test, $\mathrm{F}_{\text {calculation }}$ of experimental group in pretest and posttest obtained 30.810 while $\mathrm{F}_{\text {table }}$ was 3.91 at significance level $=0.05$. Thus, $\mathrm{F}_{\text {calculation }}>\mathrm{F}_{\text {table }}$ which means that cooperative learning was proven in increasing student's speaking ability of Indonesian Language and Literature Education Department. The improvement of speaking

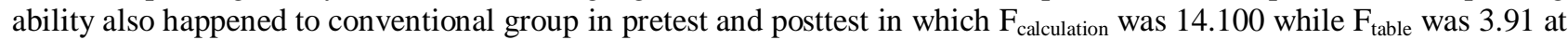
the significance level $=0.05$. However, the research results showed that cooperative learning was better in improving speaking ability than conventional learning.

After having treatment, the student's achievement in speaking ability showed differences between taught by cooperative and conventional learning. The students' average score of speaking ability by cooperative learning was 18.9875, higher than the ones by conventional learning which obtained 17.4500. Statistically, both speaking ability scores are different because $F_{\text {calculation }}$ was 11.380 while $F_{\text {table }}$ was 3.91 at the significance level $=0.05$. Since $F_{\text {calculation }}>$ $F_{\text {table }}$, it can be concluded that cooperative learning gave significant influence in improving speaking ability of students at Department of Indonesian Language and Literature Education. The result of questionnaire also indicated that cooperative learning is better than conventional one because many students preferred to use cooperative learning than conventional one.

The questionnaire result showed that the cooperative method is better than the previous one in terms of students' motivation. They have enjoyable learning in speaking and the feel confident to speak in front of the class as they had previously performed in a small group.

The lecturers gave positive responses on teaching speaking by cooperative approach. They felt more confident in implementing one of innovative learning due to the teaching guidance of speaking. These positive responses indicated that the development of speaking learning model at university level by cooperative approach was accepted. The acceptance of cooperative learning in teaching speaking is expected to bring better speaking teaching in the future, particularly at the university level. By cooperative learning, students who are reluctant to speak in front of the class will enjoy and dare to speak in front of others. They will change their thoughts from assuming speaking as difficult skill to be the easy one.

Based on the observation result during the learning process of speaking in the class, a description of students' activity and motivation was obtained as follows: (1) most students were active, creative, and could cooperate in group, (2) the students dared to speak both in group/in front of the class, (3) the students were pleased as the learning process began with many exercises in group. The lecturers and students then gave ovation and adulation to the performers. Therefore, the students did not feel shy and distressing to express ideas and thoughts coherently because they already have had rehearsal in small group. In terms of students' work, all groups could do the assignment well due to the given real example which can be seen, observed, and compared so that the students can distinguish between well-prepared and unprepared public speaking.

\section{The Discussion on Model Effectiveness Test}

The test on the effectiveness of cooperative approach toward students' speaking ability of Indonesian Language and Literature Education Department involved lecturers and students. This experimental study which invoked two groups i.e. experimental and control groups was conducted at Department of Indonesian Language and Literature of Bojonegoro Residency. All lecturers playing role as the collaborators in this research gave positive response on cooperative approach as the learning model. Cooperative learning formulated by Slavin (1985) means a learning model which demands students to work collaboratively in small groups of 4-6 with heterogeneous group structure.

The above research result of cooperative learning implementation is in line with the ones in previous research done by Slavin (1985) and Hertz-Lazarowitz et al (1993) which showed that CIRC-type cooperative learning was the best in improving language abilities (particularly in reading and writing). Moreover, National Reading Panel-USA (2000) recommended cooperative learning with Jigsaw and STAD types as the learning model for improving reading skill. 
Slavin (2011:26-17) stated that a study on cooperative learning which focuses on group and individual accountabilities reveals positive impact on students' achievement from class 2 to 12 in all subjects of all schools. Cooperative learning is not only effective in students' achievement, but it also gives positive effects on inter-groups improvement (1995b), self esteem, school manner, and good acceptance from students with special needs (Ginsburg-Block, Rorbeck, \& Fantuzzo, 2006; Shulman, Lotan, \&Whicomb, 1998; Slavin, 1995a; Slavin at al, 2003).

All of the above results showed that the implementation of cooperative learning at all school types with various school backgrounds had significant improvement. The positive influence of cooperative learning also happened at speaking learning for university level. Significant improvement on students' speaking ability because of cooperative learning occurred at Department of Indonesian Language and Literature Education in this research. It can be seen from the comparison between pretest and posttest scores. Besides, the speaking ability of students taught by cooperative learning was better than by conventional one. The research result indicated that cooperative learning gave more significant influence to student' speaking ability than conventional one.

The same research on cooperative learning carried out by Klimoviene (2012), Meng (2010), Talebi (2012), Thuy (2005) brought to conclusion that cooperative learning is more effective than conventional one. This research result also supports theirs as cooperative learning gives students the opportunities to empower their liveliness. Based on the effectiveness test, it can be concluded that cooperative learning is more effective for speaking achievement of students at Faculty of Teacher Education in Bojonegoro Residency.

Some responses on the developing model were delivered by the lecturers as the following: (1) the model has so systematic delivery technique that make the students become active, (2) the materials presentation is student-centered so that it can arouse the students' meta-cognitive, meta-affection, and meta-psychomotor, (3) the developing model of learning speaking is very beneficial for lecturers as it eases them to teach speaking and makes the students happy, (4) the model can empower the students to think critically, creatively, and innovatively as it can be seen from the students' presentation in speaking coherently, (5) the model can improve the students' learning outcomes as it can unite the students to cooperate, become responsible of their work, feel free to argue, understand faster, and easy to remember the previous learning material, (6) the model can encourage the students to learn speaking regularly and grow the sense of belonging to Indonesian Language and Literature.

In addition, the lecturers also delivered some responses on the Guidance Book of Conducting Speaking Learning by Cooperative Approach as follows: (1) the guidance book is very helpful in implementing speaking learning in class with enjoyable circumstance, (2) the book has clear explanation and can be a reference for lecturers due to its systematical learning procedure and complete appendices, (3) the book has been in line with Instructional Analysis and has good supporting materials with many examples, (4) the details on how to conduct cooperative approach in learning speaking are also presented in the book, (5) the learning presentation of the book is student-centered in which evaluation comprises cognitive, affective, and psychomotor, (6) the book assists lecturers in teaching speaking for university level as its language is so communicative that can ease them in teaching students, (7) the book provides new ways in activating students, (8) the materials inside the book are presented in understandable words completed with explanation of material delivery, some examples, and lesson plan, (9) the book guides the students to be more creative, active, and critical in speaking fluently and coherently due to its learning instructions, (10) the book has structured pattern that can ease students to understand it, (11) the book guides students to speak at university level, (12) it provides unmonotonous learning for students and gives chance for lecturers to guide students' work, (13) through this book, the students are motivated to develop their speaking skill and have preparation before they perform speaking, (14) the students have been completed with information processing through this book so that they speak confidently, (15) by this book, the students are motivated to develop their speaking skill as they already have rehearsal in small group before they perform in front of the class.

The Head of Indonesian Education Department of Ronggolawe University in Tuban also gave some responses on the guidance book as the following: (1) the learning materials of the book has been in accordance with curriculum and appropriate to students' development, (2) the learning guidance can be applied for university level and has sequence in material presentation so that the speaking learning circumstance becomes enjoyable and the students get more active during the teaching and learning process. Almost similar responses were conveyed by the Head of Indonesian Education Department of Islamic University of Darul Ulum in Lamongan. He stated that: (1) the materials are complete, deep, and in line with instructional analysis as well as Basic Competence for speaking skill at university level, (2) the book concept is credible and accurate in which procedure is easy to implement in the class, (3) the materials can arouse learning motivation as they are delivered in varied methods which support various cultural, (4) the examples applied in the book come from daily life, (5) by student-centered cooperative learning, the students become creative in speaking for university level, they tolerate each other in giving opinions, thus, their learning outcomes are satisfied.

Based on all responses delivered by lecturers, it can be concluded that the developing speaking learning model in this research is well-received by the stakeholders (lecturers and the Head of Indonesian Education Department) as its implementation is easy and all students can understand it well.

\section{CONCLUSION}


Learning speaking can be carried out by information-processing-based cooperative learning. Speaking skill needs the ability to choose message or information which will be communicated. It also requires language acquisition as a means of message conveying as well as language and non-language factors. Information processing which combined with some roles of group facilitates the students to develop potential of oral communication. The existing easy-to-remember information is related to the new one so that the students can respond and comment easily. The inhibitor factor of each student will be overcome through motivation, evaluation, and reward given to each group. The result of effectiveness test on the model by instruments and test indicated that the learning model of speaking by cooperative approach was effective. Thus, information-processing-based cooperative learning can improve the students' speaking ability.

\section{REFERENCES}

[1] Rahman, Zainuddin. (2005). Private And Public Speaking.Terjemahan. Rustica C. Carpio, dkk. Jakarta: Yayasan Obor Indonesia.

[2] Alibakhshi dan Padiz, (2011). The Effect of Teaching Strategic Competence on Speaking Performance of ELS Learners. Journal of Language Teaching and Research. Vol. 2 (4) pp941-947.

[3] Andayani. (2014). Pendekatan Saintifik dan Metodologi Pembelajaran Bahasa Indonesia. Surakarta: Yuma Pustaka.

[4] Arends, Richard I. (2008). Learning to Teach 1-Belajar untuk Mengajar. Yogyakarta: Pustaka Pelajar

[5] Arends, Richard I. (2008). Learning to Teach 2 - Belajar Untuk Mengajar. Yogyakarta.Pustaka Pelajar. Helly Prayitno Soetjipto Dan Sri Mulyantini Soetjipto.

[6] Arsjad, Maidar G., \& Mukti, U.S. (1988). Pembinaan Kemampuan Berbicara Bahasa Indonesia Jakarta: Erlangga.

[7] Arsjad, Maidar G., \& Mukti. (1998). Pembinaan Kemampuan Berbicara Bahasa Indonesia. Jakarta: Airlangga.

[8] Bahrani, Tahir, \& Rahmatollah Soltani. (2008). How to Teach Speaking Skill?. ELT Journaleltj. Oxfordjournals. Org, Vol 62, Iss 2, Pp 131-138.

[9] Borg, Walter \& Gall, Meredith Damien. (1983). Education Research. New York: Longman.

[10] Brown G. \& G. Yule. (1983). Teaching the Spoken Language. London: Cambridge University Press.

[11] Darmuki, Agus. (2013). Peningkatan Kemampuan Berbicara dengan Metode Kooperatif Tipe NHT Pada Mahasiswa Tingkat Satu Prodi PBSI IKIP PGRI Bojonegoro. Bojonegoro: IKIP PGRI Bojonegoro.

[12] Daryanto. (2010). Ilmu Komunikasi. Bandung: Satu Nusa.

[13] Fadillah, Ridha. (2013). Need Analysis For Developing English Learning Model In Banjarbaru Senior High. The Journal of Educational Development. Vol. 1 (1) pp. 35-40

[14] Gagne, Robert M. (1998). Principles of Instructional Design. London: Farmer Press.

[15] Hunter, James. (2011). Small Talk: Developing Fluency, Accuracy and Complexity in Speaking. Oxford Journal. Volume 32. Issue 1. Pp 1-12

[16] Jauhar, Mohammad. (2011). Implementasi PAIKEM dari Behavioristik sampai Konstruktivistik (Sebuah Pengembangan Pembelajaran Berbasis CTL). Jakarta: Prestasi Pustaka.

[17] Jehan, W. Georgia. (1979). Persuasive Speaking: Tehnik Berbicara yang Meyakinkan dan Efektif Terjemahan Sumantri Mertodiputro. Jakarta: Gunung Jati.

[18] Joyce, Bruce, Marsha Well, \& Emily Calhoun. (2009). Models of Teaching: Model-Model Pengajaran Yogyakarta: Pustaka Pelajar.

[19] Khamkhien, Attapol. (2010). Teaching English Speaking and English Speaking Tests in the Thai Context: A Reflection from Thai Perspective. Journal English Language Teaching. Vol. 3, issue 1, pp 20-24.

[20] Klimoviene, Giedre. (2006). Using Cooperative Learning to Develop Language Competence and Social Skill. Studies About Languages. Vol 8 Pp 77-83.

[21] Lazaraton, A. (2001). Teaching Oral Skills, In M Celce-Murcia (Ed.) Teaching English as a Second Foreign Language, Boston: Heinle and Heinle. Electronic Journal of Foreign Language Teaching. Vol. 2, No. 1, pp 23-28.

[22] Liao, Guoqiang. (2009). Educational Technology \& Society, Improvement of Speaking Ability Through Interrelated Skills. Journal of Language Teaching and Research. Vol. 1 (3) pp 643-646

[23] Lourdunathan, Josephine. \& Sujatha Menon. (2011). Developing Speaking Skill Through Interaction. The English Teacher Journal. University Teknologi MARA. Vol. 34. Pp 1-18.

[24] Maarof, Mazmi, Ruzy Suliza Hashim, Noraini Md. Yusof, \& Raihanah Mohd Mydin. (2012). Young Women Speak Out: Healing The Selves Through NarrativeTherapy. GEMA Online ${ }^{\text {TM }}$ Journal of Language Studies. Vol. 12(2): 393-405

[25] Marland, Michael. (1990). Seni Mengelola Kelas: Tugas dan Penampilan Seorang Pendidik. Semarang : Dahar Prize.

[26] Martaya, A. Widya BA. (1985). Kreatif Berwicara. Yogyakarta: Kanisius.

[27] Meng, Jing. (2010). Cooperative Learning Method in the Practice of English Reading and Speaking. Journal of Language Teaching and Research. Vol. 1 (5) pp 701-703.

[28] Moiinvaziri, Marjan. (2014). Students' Voice: A Needs Analysis of University General English Course in Iran. Gema Online Journal of Language Studies. 14(1), 57-75

[29] Nurgiantoro, Burhan . (2001). Penilaian dalam Pembelajaran Bahasa dan Sastra. Yogyakarta: BPFE.

[30] Nurgiyantoro, Burhan. (2011). Penialaian Otentik dalam Pembelajaran Bahasa. Yogyakarta: Gadjah Mada University Press.

[31] Pan, Lili. (2010). International Students in English-Speaking Universities: A Study of Public Speaking in Korean Educational Chinese Students. Journal of Language Teaching and Research. Vol. 1 (6) pp 922-925.

[32] Paris, Leo F. (2001). The Importance of Communication and Public-Speaking Skills. Journal of Environmental Health. Vol. 63 (9) $\mathrm{pp} 44-45$

[33] Ramelan. (1978). Penguasaan dan Keterampilan Berbahasa. Lembaran Ilmu Pengetahuan VII.2:22 Semarang IKIP Semarang Press. 
[34] Rido, Akhyar, Noraini Ibrahim \& Radha M.K. Nambiar. (2013). Interaction Strategies of Master Teacher in Indonesian Vocational Classroom: A case Study. 3L Journal of Language Teaching, Linguistics and Literature. Vol.21(3): 85-98.

[35] Riyanto, Yatim. (2010). Paradigma Baru Pembelajaran sebagai Referensi bagi Pendidik dalam Implementasi Pembelajaran yang Efektif dan Berkualitas. Jakarta: Kencana.

[36] Schunk, Dale H. (2012). Learning Theories An Education Perspective. Teori-Teori Pembelajaran Perspektif Pendidikan. Yogyakarta: Pustaka Pelajar.

[37] Slavin, Robert E. (2009). Cooperative Learning: Theory, Research, and Practice. Boston: Allymand Bacon.

[38] St. Y. Slamet. (2008). Keterampilan Berbahasa. Surakarta: UNS Press.

[39] Sugiyanto. (2010). Model-model Pembelajaran Inovatif. Surakarta: Panitia Sergur Rayon 113.

[40] Sugiyono. (2011). Metode Penelitian Pendekatan Kuantitatif, Kualitatif, dan R\&D.Bandung: Alfabeta.

[41] Sukmadinata, Nana Syaodih. (2007). Metode Penelitian Pendidikan. Bandung: Remaja Rosda Karya.

[42] Suryobroto, B. (1997). Proses BELAJAR Mengajar di Sekolah. Jakarta : Rineka Zuchdi,

[43] Talebi, Ferina. (2012). The Impact of Cooperative Learning on Oral Proficiency. Mediterranean Journal of Social Sciences. Vol 3. Iss 3. Pp.75-79.

[44] Tarigan, Djago dkk. (1997). Pengembangan Keterampilan Berbicara. Jakarta: Debdikbud Bagan Proyek Penataran Guru SLTP Setara DIII.

[45] Tarigan, Henry Guntur. (2008). Berbicara Sebagai Suatu Keterampilan Berbahasa. Bandung: Angkasa.

[46] Taylor, Steven J. \& Bogdan, Robert. (1984). Introduction to Qualitative Research Method. New York: A Wiley-interscience Publication: John Willey and Sons.

[47] Thornbury, Scott. (2001). How to Teach Speaking. Tanpa Kota: Longman.

[48] Thuy, Le Thi Bich. (2005). An Action Research on the Application of cooperative Learning to Teaching Speaking. TESOL. Journal, Vol 1, pp. 332-349.

[49] Tim Penyusun. (2012). Model Pembelajaran Aktif. Semarang: IKIP PGRI Press.

[50] Travis, Peter. (2011). Overview of Splendid Speaking Website. Studies in Self-Access Learning Journal. Volume 2, Issue 1, hal $39-42$.

[51] Wardani, I.G.A.K, Prasetyo Irawan, Suciati. (1997). Teori Belajar, Motivasi dan Keterampilan Mengajar. Pekerti.1997.Dirjen Dikti, Depdikbud.

[52] Winkel, W.S. (1996). Psikologi Pengajaran. Jakarta: Gramedia.

Agus Darmuki is a student of Doctoral Program at State University of Sebelas Maret, Surakarta, majoring Indonesian Language Education. He works as a lecturer of Indonesian Language and Literature Education Department, Faculty of Language and Art Education, IKIP PGRI Bojonegoro, East Java, Indonesia. His current research interest includes various models/strategies to improve speaking skill.

Andayani is a Professor at Doctoral Program Degree of Sebelas Maret University, Surakarta. Her main research interest is developing learning model for Indonesian language in international area.

Joko Nurkamto is a Professor at Doctoral Program of Sebelas Maret University, Surakarta and a Dean of Teacher Training and Education Faculty at the same university. He becomes the President of TEFLIN with current research interest of developing learning model using communicative approach for English Language.

Kundharu Saddhono is a lecturer at Doctoral Program of Sebelas Maret University, Surakarta as well as the Head of Research and Community Devotion Institution of the same university. He has accomplished various researches particularly in Language and Linguistics fields. 